\title{
Disease-related knowledge, health behaviours and clinical outcomes following an educational intervention in patients with diabetes according to their health literacy level: a systematic review
}

Gabriela Suélen da Silva Chaves ${ }^{1}$ (D), Raquel Britto ${ }^{1}$ (1), Paul Oh² (1), Gabriela Lima de Melo Ghisi ${ }^{2 *}$ (1)

\begin{abstract}
Background: The effectiveness of education programs designed to improve disease-related knowledge and change behaviours in people with diabetes has been established. Low health literacy $(\mathrm{HL})$ is considered a barrier to improving health outcomes in people with diabetes. The evidence of the effects of education programs considering $\mathrm{HL}$ levels in diabetes has not been previously systematically reviewed. Aim: This systematic review aimed to verify the impact of education on patients' knowledge, health behaviour change and clinical outcomes in patients with diabetes with low and marginal Health Literacy $(\mathrm{HL})$. Methods: A literature search of electronic databases was conducted for published articles from database inception to April 2020. Eligible articles included assessment of $\mathrm{HL}$, disease-related knowledge, health behaviours (physical activity, diet, smoking cessation, medication adherence, self-care), and clinical outcomes (diabetes management based on A1C values, self-efficacy, perceived susceptibility of complications, self-reported medical care, patient activation, and diabetes-related distress) in diabetes patients that receive any type of education intervention. Results: Overall, 8 articles were included, of which 4 (50\%) were RCTs. Four studies were considered "fair" quality. The most used screening instrument to assess HL was the Test of Functional Health Literacy in Adults short form (S-TOFHLA; $n=5,62.5 \%$ ). All studies showed improvement in disease-related knowledge and behaviour after an education program, regardless of $\mathrm{HL}$ level. The overall quality of the evidence of the studies was graded as low to very low according to the GRADE scale. Included studies differed substantially in their education programs characteristics, such as mode of delivery and intervention content. Conclusion: Educational interventions can improve knowledge, change behaviour and improve clinical outcomes of diabetic patients with low or marginal health literacy.
\end{abstract}

Keywords: Health Literacy; Health Outcomes; Diabetes Mellitus; Education; Systematic Review.

Universidade Federal de Minas Gerais Ciências da Reabilitação, Belo Horizonte, MG, Brasil

2 University Health Network, Cardiovascular Prevention and Rehabilitation Program, Toronto Rehabilitation Institute, Toronto, Canada

\section{*Corresponding author: \\ Gabriela Lima de Melo Ghisi \\ 347 Rumsey Road \\ M4G 1R7, Toronto, Ontario, Canada \\ Tel: +1 (416) 597-3422 x. 5223 / \\ Fax: +1 (416) 425-0301 \\ Email: gabriela.meloghisi@uhn.ca}

Submitted: March 06, 2021.

Accepted: August 04, 2021.

Study conducted at: This is a systematic

review - so not required.

Ethical approval: This is a systematic review so not applicable.

Clinical Trial Registration: https://osf.

io/8qmg5/

\section{How to cite}

Chaves GSS, Britto R, Oh P, Ghisi GLM. Disease-related knowledge, health behaviours and clinical outcomes following an educational intervention in patients with diabetes according to their health literacy level: a systematic review. Cardiorespir Physiother Crit Care Rehabil. 2021;1:e42809. https://doi.org/10.4322/2675-9977.cpcr.42809

\section{How can the results of this study be used in clinical practice?}

- Healthcare providers should measure their patients' health literacy level and create their care plan in accordance to this characteristic.

- Educational strategies are important tools in the care of diabetic patients, even the ones with low to marginal health literacy.

- $\quad$ Disease-related knowledge of diabetes patients should be assessed.

This an Open Access article published and distributed under a Creative Commons Attribution NonComercial ShareAlike License which permits unrestricted non-commercial use, distribution, and reproduction in any medium provided the original work is properly cited and is not represented as endorsing the use made of the work. Further, any new works must be made av 


\section{Introduction}

Diabetes is a chronic disease that affects more than 460 million people worldwide ${ }^{1}$. About 5 million adults died from diabetes in 2015 and the number of deaths is set to rise sharply by $2040^{1,2}$. Furthermore, it is one of the most costly diseases, being associated with $12 \%$ of global health expenditure in health services, loss of productivity and disability ${ }^{1}$. The most prevalent type of diabetes is type 2, which is directly related to obesity and is totally preventable $\mathrm{e}^{1,2}$. Global organizations such as the International Diabetes Federation (IDF) and the World Health Organization (WHO) have proposed preventive measures for the disease to reduce costs and promote quality of life for people with diabetes ${ }^{1-3}$. One of these measures is patient education. Education, self-management, and empowerment are considered key points in managing diabetes $^{1-4}$.

Patient education is defined as "[...] the process by which health professionals - including physiotherapists - and others impart information to patients that will alter their health behaviours or improve their health status" 5:25. Research has demonstrated a positive effect of diabetes education in prevention ${ }^{1,3,6}$, knowledge ${ }^{1,3}$, behaviour change $\mathrm{e}^{1,3}$, and avoidance of complications related to the disease $e^{3,6}$. The true goal of diabetes education should always be to improve patients' self-management abilities. This change can help them navigate through daily challenges in their care and ultimately promote short- and long-term quality of life ${ }^{7-9}$. However, studies have shown that only $20 \%$ of all patients with diabetes receive information about diabetes complications and risk factors from their healthcare providers ${ }^{10}$.

Health literacy (HL) addresses personal and organizational components. Personal health literacy is defined as the degree to which individuals can find, understand, and use information and services to inform health-related decisions and actions for themselves and others. Organizational health literacy is the degree to which organizations equitably enable individuals to find, understand, and use information and services to inform health-related decisions and actions for themselves and others ${ }^{11}$. Inadequate/low and marginal HL is common in patients with chronic diseases (including patients with diabetes), and considered a potential barrier to improve disease-related knowledge ${ }^{12}$, behaviour change, and better health outcomes ${ }^{13-15}$. Adequate health literacy in the context of diabetes includes many skills that are critical to patients for managing their condition and navigating the health care environment, including reading labels and pill bottles, comprehending appointment information and following verbal directions ${ }^{16}$.

Previous systematic reviews have confirmed the clinical effectiveness of patient education models designed to patients with diabetes ${ }^{16-22}$; however, none of them have evaluated the effect of education programs on disease-related knowledge and behaviour change considering HL levels in diabetes. Furthermore, a recent systematic review has also identified a gap in the literature regarding the relationship between HL and self-efficacy ${ }^{22}$. Thus, the objective of this systematic review was to verify the impact of education on disease-related knowledge, health behaviour change and clinical outcomes in patients with diabetes with low and marginal HL.

\section{Methods}

\section{Design}

This systematic review was registered prospectively with the Open Science Framework (OSF: https://osf.io/8qmg5/). Data is reported in accordance with the Preferred Reporting Items for Systematic Reviews and Meta-Analyses (PRISMA) guidelines $^{23}$. Literature published from data inception until April 2020 was searched using the MEDLINE, PsycINFO, CINAHL, EMBASE and Cochrane CENTRAL databases, in conjunction with an information specialist. The search string explored the topics of diabetes mellitus (condition), health literacy, outcomes (knowledge, behaviour change and clinical parameters) and RCTs. Search terms were specific to each database. The search strategy for all databases is shown in the online Supplementary Material (please visit https://cpcrjournal.org/).

\section{Inclusion and exclusion criteria}

The following categories defined the inclusion criteria:

1) Design: randomized controlled trials (RCT) and quasiexperimental studies with educational interventions were included. Observational and qualitative studies were not included in this review. Reviews were identified as a source of additional primary studies.

2) Participants: patients with type I or II diabetes were considered for inclusion.

3) Intervention: any educational interventions about diabetes and its management, delivered by a healthcare provider were included. In order to be included, the educational intervention had to be described in accordance with the reporting guidelines for behaviour change interventions developed by Workgroup for intervention, development and evaluation research (WIDER) ${ }^{24}$. Specifically, at least 3 of the 8 recommended elements for intervention description had to be detailed: characteristics of those delivering the intervention (i.e. type of healthcare professional), characteristics of the recipients, the setting (i.e. time and place of intervention), mode of delivery, the intensity (i.e. contact time), the duration (i.e. number of sessions), adherence to delivery protocols, and a detailed description of the intervention content. No specific criteria was used for the comparison group in the studies to be included in the review.

4) Outcomes: studies had to either report the impact on health behaviours (named diet, physical activity, smoking cessation, medication adherence, self-care), disease-related knowledge or clinical outcomes (named diabetes management based on A1C values, self-efficacy, perceived susceptibility of complications, self-reported medical care, patient activation, and diabetes-related 
distress). In this context, self-efficacy is defined as people's beliefs in their capability to organize and execute the course of action required to deal with prospective situations ${ }^{25}$. Studies have shown that being highly self-efficacious is a key factor in successful chronic disease self-management ${ }^{26,27}$.

5) Studies published in English, Spanish or Portuguese.

\section{Data collection and analysis}

Two authors independently read the titles and abstracts identified from the initial search to select studies that met our inclusion criteria. They also retrieved full-text articles and reviewed the results to determine eligibility. Any disagreements were resolved through discussion between the two investigators and, if needed, consultation with a third author.

Data extraction was undertaken by a single reviewer and checked by a second reviewer. The Downs and Black ${ }^{28}$ scale was used to assess the quality of the studies. This tool consists of 27 items and evaluates the quality of articles in 5 areas as follows: reporting, external validity, internal validity (bias), internal validity (confounding) and power. Answers were scored 0 (no or unable to determine) or 1 (yes), except for one item in the reporting subscale, which could be scored 0,1 or 2. Total points for each article were categorized as "good", "fair", or "poor" based on the United States Preventive Services Task Force approach ${ }^{29}$.

Although some of the included studies were RCT, it was not possible to perform meta-analysis due to the great heterogeneity of the studies (i.e., different methods of intervention such as frequency, duration, intensity, ways of delivery). Thus, descriptive analysis was performed on the results. The quality of evidence was evaluated using the Grading of Recommendations, Assessment, Development, and Evaluation (GRADE) ${ }^{30}$. The evaluation was based on four factors that can reduce the evidence's quality (study limitations, the inconsistency of results, indirectness of evidence, imprecision, and publication bias).

\section{Results}

Initial searching yielded 3084 records after duplicates removed. After the screen, 174 full-articles were assessed for eligibility. Overall, 8 articles were included in this systematic review $^{31-38}$. A flow diagram depicting the search results, reasons for exclusion, and study selection is presented in Figure 1.

\section{Characteristics of included studies}

Table 1 summarizes the methodological characteristics of the 8 included studies ${ }^{31-38}$. Four studies were randomized controlled trials ${ }^{31,33-35}$ and 4 were quasi-experimental ${ }^{32,36-38}$.

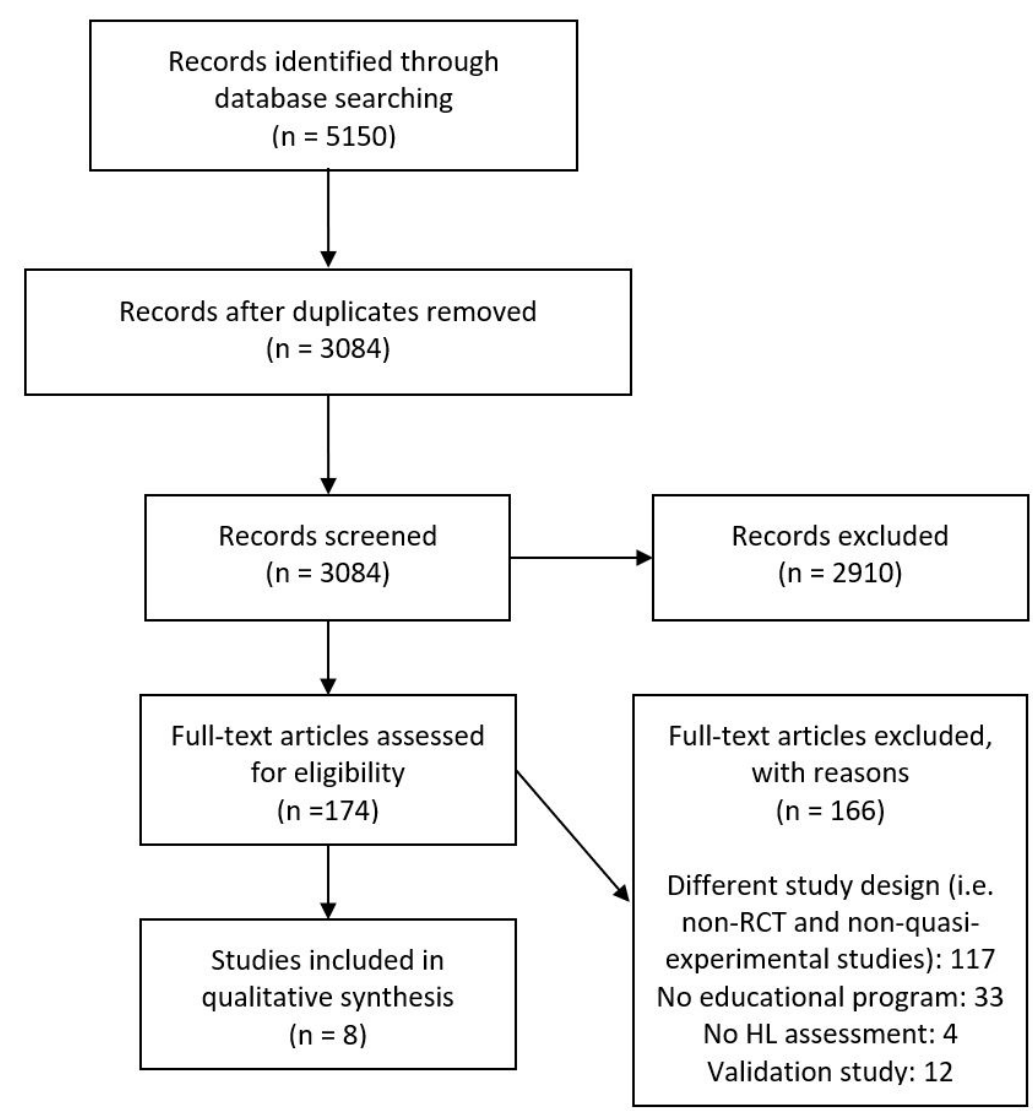

Figure 1. Flow diagram. 


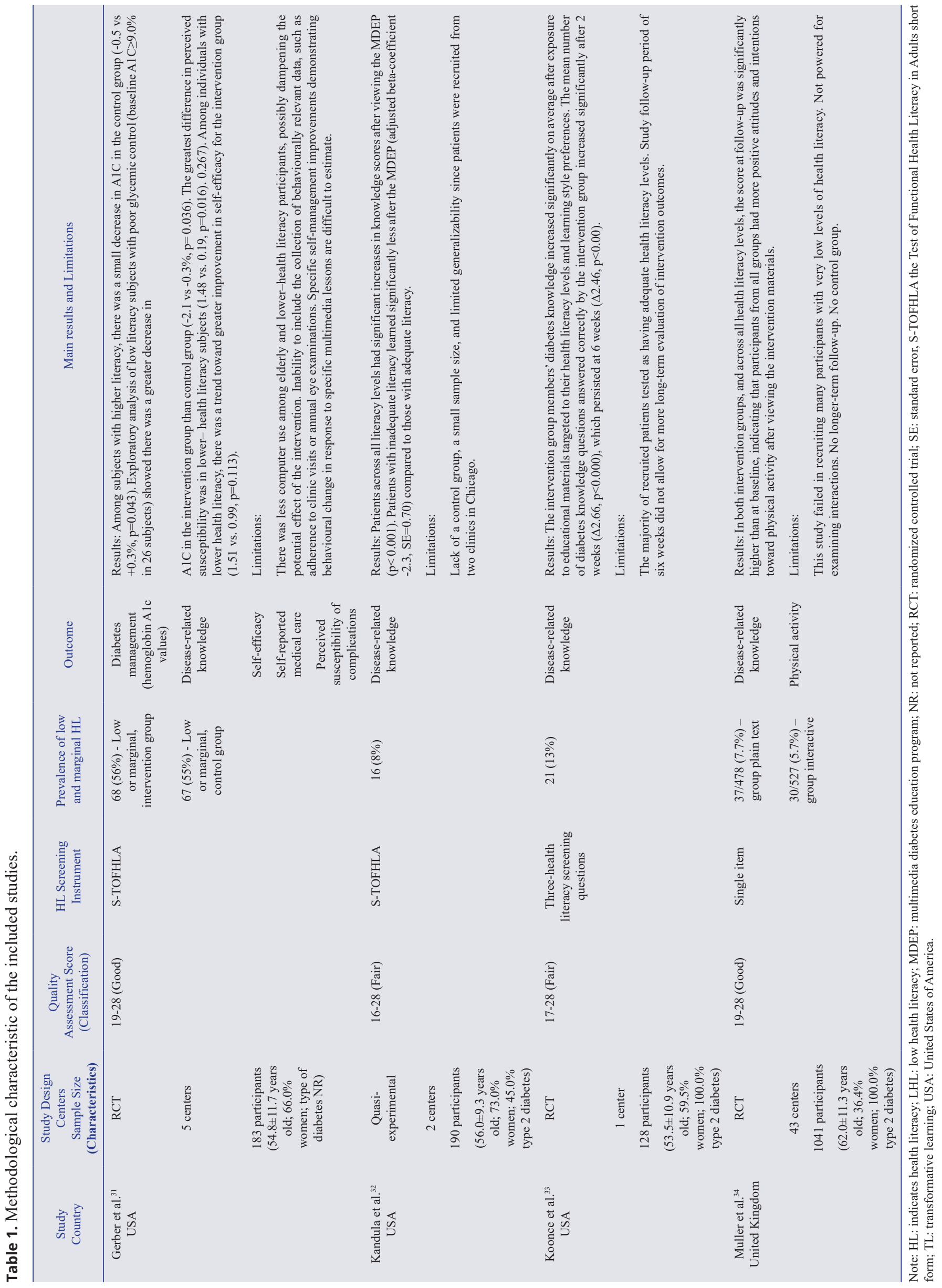




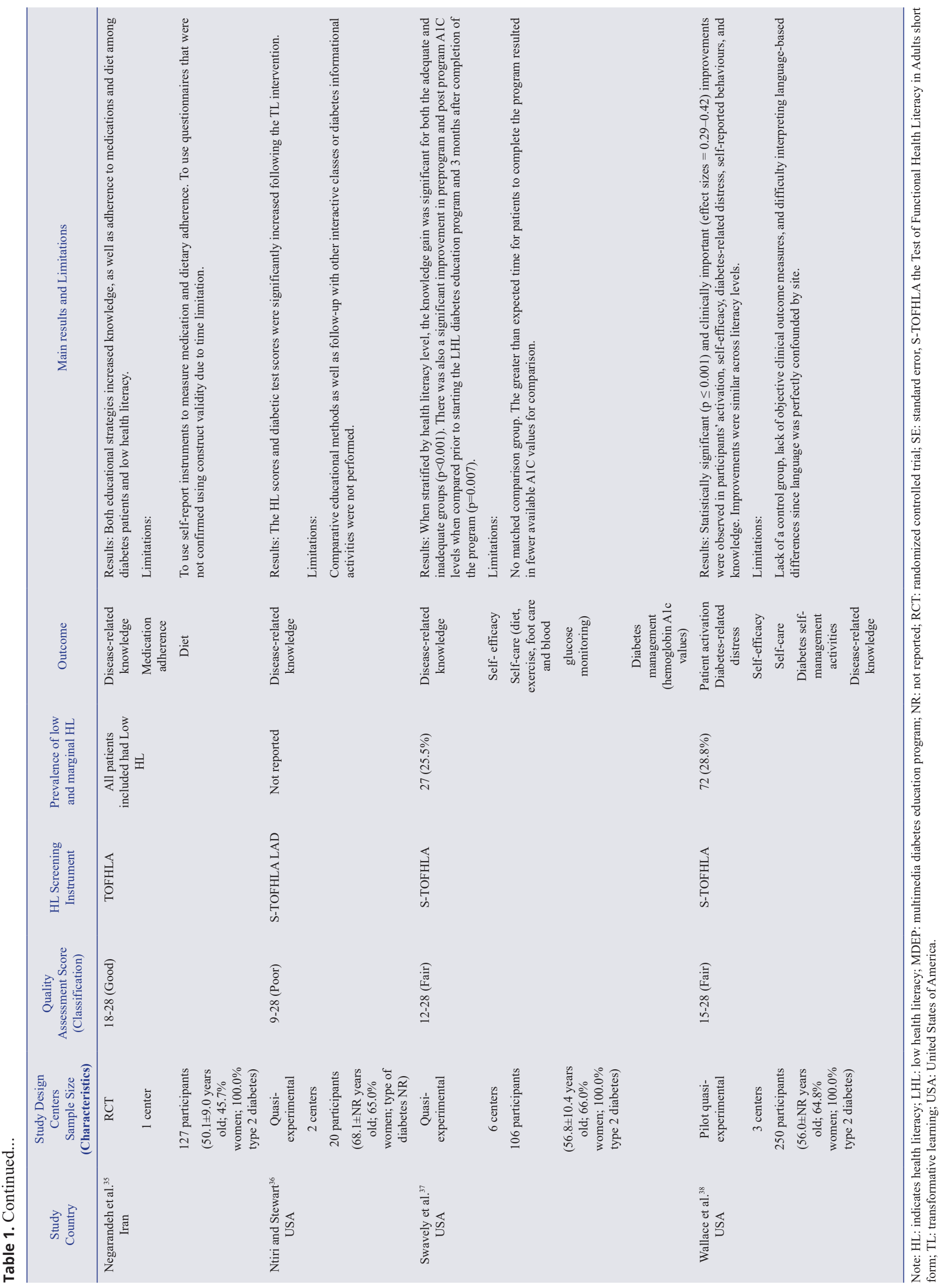


The included studies involved 2,045 study participants from 63 centers. The majority of the studies $(n=6)$ were undertaken in the United States, 1 in the United Kingdom, and 1 in Iran.

The quality ratings of the studies are also shown in Table 1. Overall, 3 studies were considered "good", 4 studies "fair" and 1 study was considered "poor" quality. The overall quality of the evidence of the studies was classified as low to very low according to the GRADE scale (Table 2).

This review identified four different tools used to screen HL in patients with diabetes: Test of Functional Health Literacy in Adults short form (S-TOFHLA) ${ }^{39}, 3$ health literacy screening questions ${ }^{40}$, a single item ${ }^{41}$ and Literacy Assessment for Diabetes $(\mathrm{LAD})^{42}$. Information regarding the different HL screening instruments used in the studies is shown in Table 1.
The prevalence of low and marginal HL is showed in Table 1. One study only included patients with low $\mathrm{HL}^{35}$, and one study did not report the number of patients with low $\mathrm{HL}^{36}$. As stated before, the most used tool was S-TOFHLA and the studies that used it reported a range from $8 \%$ to $14.4 \%$

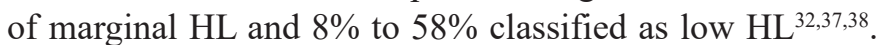
One study ${ }^{31}$ combined marginal and low scores and reported $56 \%$ for both classifications.

\section{Characteristics of educational interventions}

Table 3 summarizes the nature of educational interventions. All included studies described at least 3 of 8 recommended elements for intervention description in details. Five studies

Table 2. GRADE.

\begin{tabular}{|c|c|c|c|c|}
\hline Outcome & Effect & $\begin{array}{c}\text { Number of participants } \\
\text { (studies) }\end{array}$ & Domain assessment & Certainty in the evidence \\
\hline $\begin{array}{l}\text { Disease-related } \\
\text { knowledge }\end{array}$ & $\begin{array}{l}\text { All studies showed } \\
\text { an improvement after } \\
\text { intervention }\end{array}$ & $\begin{array}{c}\text { 2,045 participants } \\
\text { (8 studies) }\end{array}$ & $\begin{array}{l}\text { Study limitations: } \mathrm{X} \\
\text { Indirectness: } \sqrt{ } \\
\text { Imprecision: } \sqrt{ } \\
\text { Inconsistency: } \mathrm{X} \\
\text { Publication bias: } \sqrt{ }\end{array}$ & $\oplus \oplus \ominus \ominus$ \\
\hline Behaviour change - Diet & $\begin{array}{l}\text { All studies showed } \\
\text { an improvement after } \\
\text { intervention }\end{array}$ & $\begin{array}{c}483 \text { participants } \\
\text { (3 studies) }\end{array}$ & $\begin{array}{l}\text { Study limitations: } \mathrm{X} \\
\text { Indirectness: } \sqrt{ } \\
\text { Imprecision: } \mathrm{X} \\
\text { Inconsistency: } \mathrm{X} \\
\text { Publication bias: } \sqrt{ }\end{array}$ & $\oplus \ominus \ominus \ominus$ \\
\hline $\begin{array}{l}\text { Behaviour change - } \\
\text { Physical activity }\end{array}$ & $\begin{array}{l}\text { All studies showed } \\
\text { an improvement after } \\
\text { intervention }\end{array}$ & $\begin{array}{c}\text { 1,397 participants } \\
\text { (3 studies) }\end{array}$ & $\begin{array}{l}\text { Study limitations: } \mathrm{X} \\
\text { Indirectness: } \sqrt{ } \\
\text { Imprecision: } \sqrt{ } \\
\text { Inconsistency: } \mathrm{X} \\
\text { Publication bias: } \sqrt{ }\end{array}$ & $\oplus \oplus \ominus \ominus$ \\
\hline $\begin{array}{c}\text { Clinical outcome - A1c } \\
\text { values }\end{array}$ & $\begin{array}{l}\text { One study showed } \\
\text { improvement after } \\
\text { intervention }\end{array}$ & $\begin{array}{c}289 \text { participants } \\
\text { (2 studies) }\end{array}$ & $\begin{array}{l}\text { Study limitations: } \mathrm{X} \\
\text { Indirectness: } \mathrm{X} \\
\text { Imprecision: } \mathrm{X} \\
\text { Inconsistency: } \mathrm{X} \\
\text { Publication bias: } \sqrt{ }\end{array}$ & $\oplus \ominus \ominus \ominus$ \\
\hline $\begin{array}{c}\text { Clinical outcome - Self- } \\
\text { efficacy }\end{array}$ & $\begin{array}{l}\text { All studies showed } \\
\text { an improvement after } \\
\text { intervention }\end{array}$ & $\begin{array}{c}539 \text { participants } \\
\text { (3 studies) }\end{array}$ & $\begin{array}{l}\text { Study limitations: } \mathrm{X} \\
\text { Indirectness: } \mathrm{X} \\
\text { Imprecision: } \sqrt{ } \\
\text { Inconsistency: } \mathrm{X} \\
\text { Publication bias: } \sqrt{ }\end{array}$ & $\oplus \ominus \ominus \ominus$ \\
\hline
\end{tabular}

High certainty $\oplus \oplus \oplus \oplus$, moderate certainty $\oplus \oplus \oplus \ominus$, low certainty $\oplus \oplus \ominus \ominus$ and very low certainty $\oplus \ominus \ominus \ominus . \sqrt{ }$ not serious limitations; X serious limitations. 
Table 3. Characteristics about the nature of educational interventions.

\begin{tabular}{|c|c|c|c|c|c|c|}
\hline $\begin{array}{l}\text { Study } \\
\text { Country }\end{array}$ & $\begin{array}{l}\text { Health provider } \\
\text { delivering the } \\
\text { intervention }\end{array}$ & Setting & Delivery format & $\begin{array}{l}\text { Intensity: } \\
\text { - Contact time } \\
\text { - Frequency of } \\
\text { each educational } \\
\text { session }\end{array}$ & $\begin{array}{c}\text { Mean number } \\
\text { of educational } \\
\text { sessions }\end{array}$ & Education content \\
\hline \multirow[t]{7}{*}{$\begin{array}{c}\text { Gerber et al. }{ }^{31} \\
\text { USA }\end{array}$} & \multirow[t]{7}{*}{ NR } & \multirow[t]{7}{*}{ Outpatient clinic } & \multirow[t]{7}{*}{ Computer-based } & \multirow[t]{7}{*}{ NR } & \multirow[t]{7}{*}{ NR } & $\begin{array}{l}\text { Introduction to } \\
\text { diabetes }\end{array}$ \\
\hline & & & & & & $\begin{array}{l}\text { Blood glucose } \\
\text { management }\end{array}$ \\
\hline & & & & & & $\begin{array}{l}\text { Oral medications } \\
\text { and insulin }\end{array}$ \\
\hline & & & & & & $\begin{array}{l}\text { Nutrition and } \\
\text { physical activity }\end{array}$ \\
\hline & & & & & & $\begin{array}{l}\text { Depression and } \\
\text { stress }\end{array}$ \\
\hline & & & & & & Oral hygiene \\
\hline & & & & & & $\begin{array}{l}\text { Prevention of } \\
\text { complications } \\
\text { (including } \\
\text { eye, foot, } \\
\text { cardiovascular, and } \\
\text { kidney diseases) }\end{array}$ \\
\hline \multirow{2}{*}{$\begin{array}{c}\text { Kandula et al. }{ }^{32} \\
\text { USA }\end{array}$} & \multirow[t]{2}{*}{ NR } & \multirow[t]{2}{*}{ Outpatient clinic } & \multirow[t]{2}{*}{ Computer-based } & \multirow[t]{2}{*}{5 minutes } & \multirow[t]{2}{*}{ NR } & Diabetes \\
\hline & & & & & & $\begin{array}{l}\text { Blood sugar } \\
\text { control }\end{array}$ \\
\hline $\begin{array}{c}\text { Koonce et al. }{ }^{33} \\
\text { USA }\end{array}$ & NR & Outpatient clinic & $\begin{array}{l}\text { Educational } \\
\text { material (visual } \\
\text { and read) }\end{array}$ & NR & NR & Diabetes \\
\hline \multirow[t]{2}{*}{$\begin{array}{l}\text { Muller et al. }{ }^{34} \\
\text { UK }\end{array}$} & \multirow[t]{2}{*}{$\begin{array}{l}\text { Team of health } \\
\text { researchers }\end{array}$} & \multirow[t]{2}{*}{ Outpatient clinic } & $\begin{array}{l}\text { Web-based } \\
\text { materials Plain- } \\
\text { text }\end{array}$ & NR & \multirow[t]{2}{*}{ NR } & Physical activity \\
\hline & & & $\begin{array}{l}\text { Web-based } \\
\text { version }\end{array}$ & & & \\
\hline \multirow{3}{*}{$\begin{array}{l}\text { Negarandeh et al. }{ }^{35} \\
\text { Iran }\end{array}$} & \multirow[t]{3}{*}{ Nurse } & \multirow[t]{3}{*}{ Outpatient clinic } & Teach-back & 20 minutes & \multirow[t]{3}{*}{ NR } & Diabetes \\
\hline & & & Pictorial image & Three weekly & & Medication \\
\hline & & & $\begin{array}{l}\text { Both individually } \\
\text { in a private room }\end{array}$ & sessions & & Diet \\
\hline \multirow{4}{*}{$\begin{array}{c}\text { Ntiri and Stewart } \\
\text { USA }\end{array}$} & \multirow[t]{4}{*}{ Nurse } & \multirow{4}{*}{$\begin{array}{l}\text { Community } \\
\text { center }\end{array}$} & \multirow[t]{4}{*}{ Educational class } & Sixty minutes & \multirow[t]{4}{*}{6} & Diabetes \\
\hline & & & & Twice a week for & & Diet \\
\hline & & & & three weeks & & Exercising \\
\hline & & & & & & Medications \\
\hline \multirow[t]{2}{*}{$\begin{array}{c}\text { Swavely et al. }{ }^{37} \\
\text { USA }\end{array}$} & \multirow[t]{2}{*}{$\begin{array}{l}\text { Diabetes } \\
\text { educators }\end{array}$} & \multirow[t]{2}{*}{ Primary care } & Individualized & \multirow{2}{*}{$\begin{array}{c}13 \text { hours of } \\
\text { education over } 12 \\
\text { weeks }\end{array}$} & \multirow[t]{2}{*}{ NR } & $\begin{array}{l}\text { Introduction to } \\
\text { the human body }\end{array}$ \\
\hline & & & Education group & & & $\begin{array}{l}\text { Information about } \\
\text { the disease state }\end{array}$ \\
\hline \multirow{5}{*}{$\begin{array}{c}\text { Wallace et al. }{ }^{38} \\
\text { USA }\end{array}$} & \multirow[t]{5}{*}{ Research assistant } & Internal medicine & In person & Three times in & NR & Diet \\
\hline & & & Telephone & one month & & Physical activity \\
\hline & & & & & & $\begin{array}{l}\text { Blood glucose } \\
\text { monitoring }\end{array}$ \\
\hline & & & & & & $\begin{array}{l}\text { Medication } \\
\text { adherence }\end{array}$ \\
\hline & & & & & & Insulin use \\
\hline
\end{tabular}

Note: NR: indicates not reported; UK: United Kingdom; USA: United States of America. 
reported that health professionals (e.g. nurse and diabetes educator) delivered the intervention ${ }^{34-38}$.

All studies reported their settings and the most prevalent was outpatient clinics, considered in five studies ${ }^{31-35}$. The most frequent modes of delivery found were computer/ web-based ${ }^{31,32,34}$ and educational group ${ }^{36,37}$. Four studies ${ }^{35-38}$ provided information about frequency of delivery, which ranged from 1 to 12 weeks. However, duration and total number of sessions were poorly reported.

Education content was focused mainly on information about diabetes (i.e.: what is diabetes, how to reduce risk and how to manage it $)^{31-33,35-38}$, nutrition ${ }^{31,35,36,38}$, and physical activity $^{31,34,36,38}$.

This review demonstrated that on average: nurses were the most frequent educator; most educational programs were delivered in outpatient clinics; computer/web-based were the most common delivery format; the most common content approached were diabetes, physical activity and diet. Few studies provided information regarding education duration and frequency, but when reported, they varied from 5 to 20 min a day of education and 1 to 12 weeks of intervention.

\section{Disease-related knowledge}

Disease-related knowledge was assessed in eight studies ${ }^{31-38}$ and seven tools were used, as follow: the Diabetes Knowledge Test, a 23-item questionnaire, used in two studies ${ }^{33,36}$; the Spoken Knowledge in Low Literacy in Diabetes (SKILLD), a 10-item tool, used in one study ${ }^{37}$; a 17-item diabetes knowledge questionnaire developed by the authors, designed to reflect the content ${ }^{32}$; a 9-item quiz created by the authors based on the intervention content ${ }^{34}$; a 9 -item instrument developed by the authors to reflect the guide's content $^{38}$; a 22 -item questionnaire ${ }^{35}$; and a scale previously developed and validated using Rasch modeling ${ }^{31}$.

Disease-related knowledge improved after intervention in all included studies. In Gerber et al. ${ }^{31}$, even though no differences between groups were found, participants with low HL demonstrated gains compared with those having high HL. In Koonce et al..$^{33}$, the intervention group improved significantly their knowledge after exposure to educational material targeted to their health literacy levels and learning style preferences. Muller et al..$^{34}$ found significant differences between groups. The interactive group scored higher than the plain-text group $(\mathrm{p}<0.001)$. In Negarandeh et al. ${ }^{35}$, results indicated that there were significant differences between the two intervention groups with control group $(p<0.001)$, however there was no differences between the two intervention groups.

Related to the quasi-experimental studies, similar results were found. Kandula et al..$^{32}$ showed that diseaserelated knowledge improved significantly after intervention $(p<0.001)$, however, patients with inadequate HL learned less compared to those with adequate HL. Ntiri and Stewart ${ }^{36}$ showed a positive effect of the intervention on disease-related knowledge. Swavely et al. ${ }^{37}$ reported that the knowledge improved after intervention in all patients, regardless HL levels. Wallace et al. ${ }^{38}$, reported statistically significant $(\mathrm{p}<0.001)$ changes in participants' knowledge when comparing baseline and post-intervention moments.

\section{Behaviour change}

Behaviour change - $\operatorname{diet}^{35,37,38}$, physical activity ${ }^{34,37,38}$, and medication adherence ${ }^{35}$ - was evaluated in four studies. Negarandeh et al. ${ }^{35}$, showed that diet and medication adherence improved significantly between the two intervention groups with control group $(\mathrm{p}<0.001)$; however, there was no differences between the two intervention groups. Muller et al. ${ }^{34}$ reported that participants from all groups improved the intention to perform physical activity after intervention, regardless the levels of HL $(p<0.001)$. Swavely et al. ${ }^{37}$ and Wallace et al. ${ }^{38}$ showed statistically significant changes $(p<0.001)$ in participants' diet and physical activity comparing baseline and post-intervention moments.

\section{Clinical outcomes}

The followed clinical outcomes were assessed: diabetes management (based on A1C values) ${ }^{31,37}$, self-efficacy ${ }^{31,37,38}$, perceived susceptibility of complications ${ }^{31}$, self-reported medical care $^{31}$, patient activation ${ }^{38}$, and diabetes-related distress ${ }^{38}$. Patient education seems to interfere mostly in selfefficacy, perceived susceptibility of complications, patient activation and diabetes-related distress.

Gerber et al. ${ }^{31}$ showed that there was no significant differences in $\mathrm{A} 1 \mathrm{C}$ values between groups. On the other hand, Swavely et al. ${ }^{37}$ identified an improvement in $\mathrm{A} 1 \mathrm{C}$ values after intervention $(\mathrm{p}=0.007)$.

Self-efficacy scores as measured on a scale of $1-10$ were significantly improved at the end of the intervention $(p<0.001)$ in Swavely et al. ${ }^{37}$ study. The same result was found in Wallace et al. ${ }^{38}$ : an improvement of self-efficacy after intervention, as well as in Gerber et al. ${ }^{31}$.Although nonsignificant, there was a trend towards greater improvement in self-efficacy for the intervention group among individuals with lower health literacy.

Gerber et al. ${ }^{31}$ showed that there was no difference between groups in self-reported medical care. However, perceived susceptibility of complications was greater for intervention group $(p=0.009)$ and greatest in low HL participants $(p=0.016)$. Lastly, Wallace et $a .^{38}$ reported that patient activation and diabetes-related distress changed significantly from baseline to study completion.

\section{Discussion}

This systematic review investigated the impact of patient education on disease-related knowledge, health behaviour change and clinical outcomes in patients with diabetes with low and marginal HL. Results suggest that educational interventions increase disease-related knowledge and change 
behaviour after education program for patients with diabetes with low health literacy. Eight studies showed that different delivery modes (i.e. web-based, phone-based, educational material, educational classes) could improve disease-related knowledge. Furthermore, studies showed that educational interventions might promote improvements in physical activity, healthier dietary habits, medication adherence, and self-efficacy.

According to Powers et al. ${ }^{43}$ diabetes education is a process to facilitate diabetes self-care. An efficient delivery involves clear communication and collaboration among the healthcare team, which can guarantee that proper interventions are being used $^{43}$. Previous studies showed that with different mode of delivery (e.g. individual, group, solo and team) educational strategies could improve outcomes such as knowledge and A $1 C^{17-19,44}$. Similar results were observed in this review, where the outcomes changed after intervention as well as when compared between intervention and control groups, regardless levels of HL.

Previous studies ${ }^{17,45,46}$ also showed that duration of intervention could vary and still promotes changes in outcomes. However, we were not able to evaluate duration in this review, because most of studies did not report details about their interventions. Furthermore, other studies ${ }^{47,48}$ are in line with this review: appropriate educational programs to this specific population could improve results and participation.

The results presented in this review should be interpreted with caution. The extensive variety of interventions, educators, content delivered and details about duration and frequency of intervention as well as different tools used to measure the outcome mitigated the use of meta-analysis and the overall quality of the evidence of the studies was classified as low to very low according to the GRADE system. Also, generalizability is limited as only English, Spanish and Portuguese articles were included.

It is important to note that included studies differed substantially in their education programs characteristics, such as mode of delivery and interventional content. Also, most of the included studies did not report details about the education provided as recommended by $\mathrm{WIDER}^{24}$, such as educator, duration and frequency of intervention. Without detailed information, it is difficult to draw conclusions on what is the most effective educational intervention that can positively impact patients with diabetes with limited HL. Finally, not all tools used to assess disease-related knowledge were validated.

In conclusion, this systematic review suggests that educational programs for diabetic patients with low to marginal health literacy could improve disease-related knowledge, behaviour change and clinical outcomes, even though we were not able to perform meta-analysis. It is expected that future randomized controlled trial might be conducted in a way to facilitate pooled data in meta-analysis.

Healthcare professionals involved with patients with diabetes should recognize the importance of educational programs for patients with low or marginal HL. They should implement strategies to educate diabetic patients with low or marginal HL to be able to manage their health condition. Also, assessing HL and disease-related knowledge of patients using validated instruments should be included in the standard of care of these patients.

\section{Funding}

Gabriela SS Chaves and Raquel R Britto were supported by the Foundation for Supporting Research in the state of Minas Gerais (FAPEMIG). Raquel R Britto was also supported by the National Council of Scientific and Technological Development (CNPq).

\section{Conflict of interest}

The authors declared no potential conflicts of interest with respect to the research, authorship, and/or publication of this article.

\section{Acknowledgements}

The authors would like to acknowledge Maureen Pakosh, MISt for undertaking the literature search supporting this systematic review.

\section{References}

1. IDF: International Diabetes Federation [Internet]. IDF Diabetes Atlas. 9th ed. Brussels, Belgium: IDF; 2019 [cited 2021 May 18]. Available from: http://www.diabetesatlas.org

2. IDF: International Diabetes Federation. International Curriculum for Diabetes Health Professional Education. Brussels, Belgium: IDF; 2008. $116 \mathrm{p}$.

3. WHO: World Health Organization. Global Report on Diabetes. Switzerland: WHO; 2016

4. Rydén L, Grant PJ, Anker SD, Berne C, Cosentino F, Danchin $\mathrm{N}$, et al. ESC Guidelines on diabetes, pre-diabetes, and cardiovascular diseases developed in collaboration with the EASD: the Task Force on diabetes, pre-diabetes, and cardiovascular diseases of the European Society of Cardiology (ESC) and developed in collaboration with the European Association for the Study of Diabetes (EASD). Eur Heart J. 2013;34(39):3035-87. http://dx.doi.org/10.1093/eurheartj/eht108. PMid:23996285.

5. Koongstvedt $\mathrm{P}$. The managed health care handbook. Gaithersburg: Aspen Publishers; 2001.

6. Deakin T, McShane CE, Cade JE, Williams RD. Group based training for self- management strategies in people with type 2 diabetes mellitus. Cochrane Database Syst Rev. 2005;2(2):CD003417. http://dx.doi. org/10.1002/14651858.CD003417.pub2. PMid:15846663.

7. Snoek F, Visser A. Improving quality of life in diabetes: how effective is education? Patient Educ Couns. 2003;51(1):1-3. http://dx.doi. org/10.1016/S0738-3991(03)00204-0. PMid:12915274.

8. Beck J, Greenwood DA, Blanton L, Bollinger ST, Butcher MK, Condon JE, et al. 2017 National standards for diabetes self-management education and support. Diabetes Educ. 2017;43(5):449-64. http:// dx.doi.org/10.1177/0145721717722968. PMid:28753378.

9. Tang PC, Overhage JM, Chan AS, Brown NL, Aghighi B, Entwistle MP, et al. Online disease management of diabetes: engaging and motivating patients online with enhanced resources diabetes (EMPOWER-D), a randomized controlled trial. J Am Med Inform Assoc. 
2013;20(3):526-34. http://dx.doi.org/10.1136/amiajnl-2012-001263. PMid:23171659.

10. Bohanny W, Wu SFV, Liu CY, Yeh SH, Tsay SL, Wang TJ. Health literacy, self-efficacy, and self-care behaviors in patients with type 2 diabetes mellitus. J Am Assoc Nurse Pract. 2013;25(9):495-502. http:// dx.doi.org/10.1111/1745-7599.12017. PMid:24170654.

11. U.S. Department of Health and Human Services [Internet]. Health Literacy in Healthy People 2030 [cited 2021 March 6]. Available from: https://health.gov/our-work/healthy-people/healthy-people-2030/ health-literacy-healthy-people-2030

12. White RO, Chakkalakal RJ, Presley CA, Bian A, Schildcrout JS, Wallston KA, et al. Perceptions of Provider Communication Among Vulnerable Patients With Diabetes: Influences of Medical Mistrust and Health Literacy. J Health Commun. 2016;21(Suppl 2):127-34. http:// dx.doi.org/10.1080/10810730.2016.1207116. PMid:27662442.

13. Williams MV, Baker DW, Parker MR, Nurss JR. Relationship of functional health literacy to patients' knowledge of their chronic disease. Arch Intern Med. 1998;158(2):166-72. http://dx.doi. org/10.1001/archinte.158.2.166. PMid:9448555.

14. Boren SA. A review of health literacy and diabetes: opportunities for technologies. J Diabetes Sci Technol. 2009;3(1):202-9. http://dx.doi. org/10.1177/193229680900300124. PMid:20046666.

15. Al Sayah F, Majumdar SR, Williams B, Robertson S, Johnson JA. Health Literacy and Health Outcomes in Diabetes: A Systematic Review. J Gen Intern Med. 2013;28(3):444-52. http://dx.doi. org/10.1007/s11606-012-2241-z. PMid:23065575.

16. Loveman E, Frampton GK, Clegg AJ. The clinical effectiveness of diabetes education models for Type 2 diabetes: a systematic review. Health Technol Assess. 2008;12(9):1-116, iii. http://dx.doi. org/10.3310/hta12090. PMid:18405469.

17. Steinsbekk A, Rygg LO, Lisulo M, Rise MB, Fretheim A. Group based diabetes self-management education compared to routine treatment for people with type 2 diabetes mellitus. A systematic review with meta-analysis. BMC Health Serv Res. 2012;12(1):213. http://dx.doi. org/10.1186/1472-6963-12-213. PMid:22824531.

18. Pal K, Eastwood SV, Michie S, Farmer A, Barnard ML, Peacock $\mathrm{R}$, et al. Computer-based interventions to improve self-management in adults with type 2 diabetes: a systematic review and meta-analysis. Diabetes Care. 2014;37(6):1759-66. http://dx.doi.org/10.2337/dc131386. PMid:24855158.

19. Chrvala CA, Sherr D, Lipman RD. Diabetes self-management education for adults with type 2 diabetes mellitus: A systematic review of the effect on glycemic control. Patient Educ Couns. 2016;99(6):92643. http://dx.doi.org/10.1016/j.pec.2015.11.003. PMid:26658704.

20. Mohamed A, Staite E, Ismail K, Winkley K. A systematic review of diabetes self-management education interventions for people with type 2 diabetes mellitus in the Asian Western Pacific (AWP) region. Nurs Open. 2019;6(4):1424-37. http://dx.doi.org/10.1002/nop2.340. PMid:31660170.

21. Dahal PK, Hosseinzadeh H. Association of health literacy and diabetes self-management: a systematic review. Aust J Prim Health. 2019;25(6):526-33. http://dx.doi.org/10.1071/PY19007. PMid:31710832.

22. Caruso R, Magon A, Baroni I, Dellafiore F, Arrigoni C, Pittella F, et al. Health literacy in type 2 diabetes patients: a systematic review of systematic reviews. Acta Diabetol. 2018;55(1):1-12. http://dx.doi. org/10.1007/s00592-017-1071-1. PMid:29129000.

23. Page MJ, McKenzie JE, Bossuyt PM, Boutron I, Hoffmann TC, Mulrow CD, et al. The PRISMA 2020 statement: an updated guideline for reporting systematic reviews. BMJ. 2021;372(71):n71. http://dx.doi. org/10.1136/bmj.n71. PMid:33782057.

24. WIDER Group. [Internet]. WIDER Recommendations to Improve Reporting of the Content of Behaviour Change Interventions.
WIDER Group; 2008 [cited 2020 July 1]. Available from: http:// interventiondesign.co.uk/?page_id=9

25. Williams BW, Kessler HA, Williams MV. Relationship among practice change, motivation, and self-efficacy. J Contin Educ Health Prof. 2014;34(Suppl 1):S5-10. http://dx.doi.org/10.1002/chp.21235. PMid:24935884.

26. D'Souza MS, Karkada SN, Parahoo K, Venkatesaperumal R, Achora S, Cayaban ARR. Self-efficacy and self-care behaviours among adults with type 2 diabetes. Appl Nurs Res. 2017;36:25-32. http://dx.doi. org/10.1016/j.apnr.2017.05.004. PMid:28720235.

27. Dehghan H, Charkazi A, Kouchaki GM, Zadeh BP, Dehghan BA, Matlabi M, et al. General self-efficacy and diabetes management self-efficacy of diabetic patients referred to diabetes clinic of Aq Qala, North of Iran. J Diabetes Metab Disord. 2017;16(1):8. http://dx.doi. org/10.1186/s40200-016-0285-z. PMid:28239598.

28. Downs SH, Black N. The feasibility of creating a checklist for the assessment of the methodological quality both of randomised and non-randomised studies of health care interventions. J Epidemiol Community Health. 1998;52(6):377-84. http://dx.doi.org/10.1136/ jech.52.6.377. PMid:9764259.

29. Harris RP, Helfand W, Woolf SH, Lohr KN, Mulrow CD, Teutsch SM, et al. Current methods of the US Preventive Services Task Force: a review of the process. Am J Prev Med. 2001;20(3, Suppl):21-35. http://dx.doi.org/10.1016/S0749-3797(01)00261-6. PMid:11306229.

30. Murad MH, Mustafa RA, Schünemann HJ, Sultan S, Santesso N. Rating the certainty in evidence in the absence of a single estimate of effect. Evid Based Med. 2017;22(3):85-7. http://dx.doi.org/10.1136/ ebmed-2017-110668. PMid:28320705.

31. Gerber BS, Brodsky IG, Lawless KA, Smolin LI, Arozullah AM, Smith EV, et al. Implementation and evaluation of a low-literacy diabetes education computer multimedia application. Diabetes Care. 2005;28(7):1574-80. http://dx.doi.org/10.2337/diacare.28.7.1574. PMid:15983303.

32. Kandula NR, Nsiah-Kumi PA, Makoul G, Sager J, Zei CP, Glass S, et al. The relationship between health literacy and knowledge improvement after a multimedia type 2 diabetes education program. Patient Educ Couns. 2009;75(3):321-7. http://dx.doi.org/10.1016/j.pec.2009.04.001. PMid:19395223.

33. Koonce TY, Giuse NB, Kusnoor SV, Hurley S, Ye F. A personalized approach to deliver health care information to diabetic patients in community care clinics. J Med Libr Assoc. 2015;103(3):123-30. http:// dx.doi.org/10.3163/1536-5050.103.3.004. PMid:26213503.

34. Muller I, Rowsell A, Stuart B, Hayter V, Little P, Ganahl K, et al. Effects on engagement and health literacy outcomes of web-based materials promoting physical activity in people with diabetes: an international randomized trial. J Med Internet Res. 2017;19(1):e21. http://dx.doi. org/10.2196/jmir.6601. PMid:28115299.

35. Negarandeh R, Mahmoodi H, Noktehdan H, Heshmat R, Shakibazadeh E. Teach back and pictorial image educational strategies on knowledge about diabetes and medication/dietary adherence among low health literate patients with type 2 diabetes. Prim Care Diabetes. 2013;7(2):111-8. http://dx.doi.org/10.1016/j.pcd.2012.11.001. PMid:23195913.

36. Ntiri DW, Stewart M. Transformative learning intervention: effect on functional health literacy and diabetes knowledge in older African Americans. Gerontol Geriatr Educ. 2009;30(2):100-13. http://dx.doi. org/10.1080/02701960902911265. PMid:19440898.

37. Swavely D, Vorderstrasse A, Maldonado E, Eid S, Etchason J. Implementation and evaluation of a low health literacy and culturally sensitive diabetes education program. J Healthc Qual. 2013;36(6):1623. http://dx.doi.org/10.1111/jhq.12021. PMid:23799918.

38. Wallace AS, Seligman HK, Davis TC, Schillinger D, Arnold CL, Bryant-Shilliday B, et al. Literacy-appropriate educational materials 
and brief counseling improve diabetes self-management. Patient Educ Couns. 2009;75(3):328-33. http://dx.doi.org/10.1016/j. pec.2008.12.017. PMid:19167857.

39. Baker DW, Williams MV, Parker RM, Gazmararian JA, Nurss J. Development of a brief test to measure functional health literacy. Patient Educ Couns. 1999;38(1):33-42. http://dx.doi.org/10.1016/ S0738-3991(98)00116-5. PMid:14528569.

40. Chew LD, Griffin JM, Partin MR, Noorbaloochi S, Grill JP, Snyder A, et al. Validation of screening questions for limited health literacy in a large VA outpatient population. J Gen Intern Med. 2008;23(5):561-6. http://dx.doi.org/10.1007/s11606-008-0520-5. PMid:18335281.

41. Chew LD, Bradley KA, Boyko EJ. Brief questions to identify patients with inadequate health literacy. Fam Med. 2004;36(8):588-94. PMid:15343421.

42. Nath CR, Sylvester ST, Yasek V, Gunel E. Development and validation of a literacy assessment tool for persons with diabetes. Diabetes Educ. 2001;27(6):857-64. http://dx.doi.org/10.1177/014572170102700611. PMid:12211925.

43. Powers MA, Bardsley J, Cypress M, Duker P, Funnell MM, Hess Fischl A, et al. Diabetes self-management education and support in type 2 diabetes: a joint position statement of the American Diabetes Association, the American Association of Diabetes Educators, and the Academy of Nutrition and Dietetics. J Acad Nutr Diet.
2015;115(8):1323-34. http://dx.doi.org/10.1016/j.jand.2015.05.012. PMid:26054423.

44. Duke SAS, Colagiuri S, Colagiuri R. Individual patient education for people with type 2 diabetes mellitus. Cochrane Database Syst Rev. 2009;1(1):CD005268. http://dx.doi.org/10.1002/14651858.CD005268. pub2. PMid:19160249.

45. Tankova T, Dakovska G, Koev D. Education and quality of life in diabetic patients. Patient Educ Couns. 2004;53(3):285-90. http://dx.doi. org/10.1016/j.pec.2003.09.013. PMid:15186865.

46. Rashed OA, Sabbah HA, Younis MZ, Kisa A, Parkash J. Diabetes education program for people with type 2 diabetes: an international perspective. Eval Program Plann. 2016;56:64-8. http://dx.doi. org/10.1016/j.evalprogplan.2016.02.002. PMid:27060766.

47. Attridge M, Creamer J, Ramsden M, Cannings-John R, Hawthorne K. Culturally appropriate health education for people in ethnic minority groups with type 2 diabetes mellitus. Cochrane Database Syst Rev. 2014;9(9):CD006424. http://dx.doi.org/10.1002/14651858.CD006424. pub3. PMid:25188210.

48. Lepard MG, Joseph AL, Agne AA, Cherrington AL. Diabetes selfmanagement interventions for adults with type 2 diabetes living in rural areas: a systematic literature review. Curr Diab Rep. 2015;15(6):608. http://dx.doi.org/10.1007/s11892-015-0608-3. PMid:25948497. 


\section{Author contributions}

GSSC: data acquisition, analysis and interpretation, writing; RB: supervision, analysis and revising manuscript; PO: supervision, analysis and revising manuscript; GLMG: conceptualization of the study, data acquisition, analysis and interpretation, writing and reviewing.

\section{Author information}

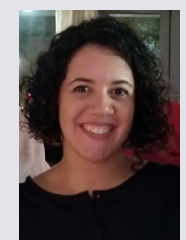

\section{Gabriela Suélen da Silva Chaves}

Graduated in physiotherapy with a PhD in the same area at the Universidade Federal de Minas Gerais (Brazil).

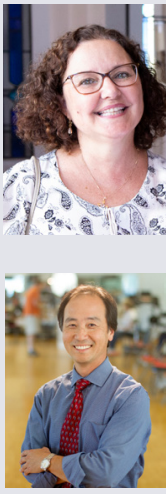

\section{Raquel Britto}

Professor of cardiopulmonary physiotherapy at the Universidade Federal de Minas Gerais (Brazil) with international experience at the University of Health Network and York University (Canada) on Cardiac Rehabilitation.

\section{Paul Oh}

The GoodLife Fitness Chair in Cardiovascular Rehabilitation and Prevention, Medical Director of the Cardiovascular Prevention and Rehabilitation Program at Toronto Rehab and a Senior Scientist at KITE, in Canada.

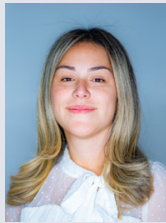

\section{Gabriela Lima de Melo Ghisi}

Scientific associate at Toronto Rehabilitation Institute, UHN, Canada. Graduated in physiotherapy at UDESC (Brazil) and has a $\mathrm{PhD}$ in Execise Sciences from University of Toronto (Canada), and two post-docs in the area (York University, Canada). 